\title{
Application of Vermicompost, Spent Mushroom Substrate, Domestic Compost and Leachate as Inoculum on Bioremediation of Oil Sludge
}

\section{Nia Rossiana*, Ida Indrawati ${ }^{\#}$ and Yulisa Mustika\#}

Faculty of Mathematic and Natural Sciences, Department of Biology, Universitas Padjadjaran, JL Raya Bandung-Sumedang Km-21, Jatinangor, Sumedang, West Java, Indonesia

\# Equally contributed

\begin{abstract}
The research on utilization of spent mushroom substrate (SMS), vermicompost (VC), domestic compost (DC) and leachate $(L)$ as inoculum of microorganisms in bioremediation of $30 \%$ oil sludge was conducted. The aim of this study was to obtain the most suitable inoculum in bioremediation of oil sludge. TPH and $\mathrm{C} / \mathrm{N}$ ratios were analyzed on 15 days of interval, while Polycyclic Aromatic Hydrocarbon (PAH) and heavy metals were measured at the beginning $(\mathrm{H}-0)$ and the end of experiment $(\mathrm{H}-45)$ for 45 days of experiment. The additional parameters such as acidity $(\mathrm{pH})$, temperature $\left({ }^{\circ} \mathrm{C}\right)$, and humidity of medium $(\%)$ were measured. The results showed that all inoculums (SMS, VC, DC and L) affect the diminution of TPH as much as $27.7 \%, 20.9 \%, 24.8 \%$ and $24.20 \%$, respectively. On the other hand, SMS and VC were able to decrease $\mathrm{C} / \mathrm{N}$ ratio as much as $18 \%$ and $4 \%$, respectively. By contrast, DC and $L$ increased $\mathrm{C} / \mathrm{N}$ ratio as much as $33 \%$ and $1.14 \%$, respectively. In this study, inoculum of SMS and $L$ were able to decrease $\mathrm{Cr}$ content (16\% and $5.88 \%$, respectively). However, $\mathrm{Hg}$ content diminished $(29 \%)$ only in oil sludge medium with SMS inoculum. The PAH compound can be degraded by all types of inoculum with carbon chain ranged from $\mathrm{C}_{6}-\mathrm{C}_{54}$ into shorter carbon chain $\left(\mathrm{C}_{6}-\mathrm{C}_{30}\right)$.
\end{abstract}

Keywords: Bioremediation; Oil sludge; Biofertilizer

\section{Introduction}

Petroleum waste is considered as industrial waste from the oil exploration and refining processes. This waste potentially produced oil sludge that contains oil, water, ash, rust, sand and other materials. The hydrocarbon compounds in oil sludge contain benzene, toluene, ethylbenzene, xylene and heavy metals that are potentially carcinogenic [1].

According to the Indonesian government regulation No. 101/2014, oil sludge is classified into the hazardous and toxic waste (B3) with accession number B 351-3. In the present work, oil sludge from PT. Pertamina Balongan is used. The latest laboratory analysis in 2016 revealed that the TPH content in the oil sludge from Balongan was $29.50 \%$, with $\mathrm{C} / \mathrm{N}$ ratio as much as 149.5 . On the other hand, the decree of Indonesian Minister of Environment No.128/ 2003 clearly states that the oil sludge with TPH contents with more than $15 \%$ was obliged to be processed prior to its utilization. Nevertheless, Chevron Indonesia argued that the petroleum-contaminated soil could be categorized safe and removed from the treatment site to the environment when the TPH content is less than $\leq 1 \%[2-4]$.

Bioremediation could be defined as a natural-clean up process to remove the hazardous chemicals by the microorganisms. During the remediation process, the microbes will degrade the hazardous material and as consequence, harmful products such $\mathrm{CO}_{2}$ will be produced [5]. Recent studies showed that utilization of various bio-fertilizers could be applied as bio-stimulators to enhance the microbial growth in degrading the oil sludge. Indeed, this concept has been applied in bioremediation process and known as "Bio-fertilizer for Bioremediation". Indeed, Pranajaya [6] reported that compost and biological fertilizer are natural materials and provide higher efficiency in TPH biodegradation as compared to synthetic materials. Moreover, recent work from Juliani and Fudhola [7] demonstrated that compost has a positive effect on the bioremediation process. Briefly, reactor with $10 \%$ of compost had significantly higher TPH reduction rate (39\%) than that of given only $5 \%$, with the best proportion of mixture between soil and oil sludge as much as $1: 1$
In the present work, biostimulation technique will be applied by adding several types of bio-fertilizers, namely the spent mushroom substrate (SMS), vermicompost (VC), domestic compost (DC) and leachate $(\mathrm{L})$, as the source of inoculum and bio-stimulators for the microbial growth to degrade the oil sludge. Additionally, the present study will test different types of bio-stimulators in order to obtain the best inoculum in degrading the Total Petroleum Hydrocarbon (TPH), Polycyclic Aromatic Hydrocarbon (PAH), C/N ratio and heavy metals in oil sludge.

\section{Materials and Methods}

\section{Experimental set up}

The present work was conducted from February to July 2017 in the laboratory of microbiology, Biology Department, Faculty of Mathematics and Natural Sciences, Padjadjaran University. The analysis of heavy metal content was done at Central Laboratory of Geological Survey, Bandung. While the TPH analysis was conducted at Nutrition Laboratory, Faculty of Animal Husbandry, Universitas Padjadjaran. Additionally, PAH analysis was realized in the Instrument Laboratory, Chemistry Department of Universitas Pendidikan Indonesia, whereas analysis of $\mathrm{C} / \mathrm{N}$ ratio was conducted in the Laboratory of Soil Chemistry, Faculty of Agriculture Universitas Padjadjaran.

"Corresponding author: Nia Rossiana, Faculty of Mathematic and Natural Sciences, Department of Biology, Universitas Padjadjaran, JL-Raya BandungSumedang Km-21, Jatinangor, Sumedang, West Java, Indonesia, Tel: +62-22 7797712 ext. 104; Fax: +62-22-7794545; E-mail: niarossiana@yahoo.com

Received December 07, 2017; Accepted December 23, 2017; Published December 30, 2017

Citation: Rossiana N, Indrawati I, Mustika Y (2017) Application of Vermicompost Spent Mushroom Substrate, Domestic Compost and Leachate as Inoculum on Bioremediation of Oil Sludge. J Pet Environ Biotechnol 8: 351. doi: 10.4172/21577463.1000351

Copyright: (C) 2017 Rossiana N, et al. This is an open-access article distributed under the terms of the Creative Commons Attribution License, which permits unrestricted use, distribution, and reproduction in any medium, provided the original author and source are credited. 
Citation: Rossiana N, Indrawati I, Mustika Y (2017) Application of Vermicompost, Spent Mushroom Substrate, Domestic Compost and Leachate as Inoculum on Bioremediation of Oil Sludge. J Pet Environ Biotechnol 8: 351. doi: 10.4172/2157-7463.1000351

Page 2 of 5

In this study, experimental method with single factor consisting four levels (the addition of SMS, VC, DC and L to degrade $30 \%$ oil sludge) was applied. The main parameters measured in this study were the number of microbial colonies $\left(\mathrm{CFU} \mathrm{mL} \mathrm{m}^{-1}\right)$, Total Petroleum Hydrocarbon (TPH), Polycyclic Aromatic Hydrocarbon (PAH), and heavy metals content, as well as $\mathrm{C} / \mathrm{N}$ ratio. TPH and $\mathrm{C} / \mathrm{N}$ ratio were analyzed within 15 days of interval while $\mathrm{PAH}$ and heavy metals were measured at the beginning (day 0 ) and end (day 45) of experiment during 45 days. On the other hand, supporting parameters consist acidity $(\mathrm{pH})$, temperature $\left({ }^{\circ} \mathrm{C}\right)$ and medium humidity (\%).

The measurement of TPH content (\%) was performed using the soxhlet method from AOAC in 1995, while $\mathrm{C} / \mathrm{N}$ ratio (\%) was measured according to Walkley and Black' protocol in 1934. Additionally, number of microbial colony $\left(\mathrm{CFU} \mathrm{mL} \mathrm{m}^{-1}\right)$ was measured using Total Plate Count (TPC) method as described in Cappuccino and Sherman in 1987. Whereas heavy metals content such as $\mathrm{Pb}, \mathrm{Ni}, \mathrm{Cd}, \mathrm{Cr}$ and $\mathrm{Hg}$ were analyzed using Atomic Absorption Spechtrophotometer method (AAS). The PAH content in this study was measured using Gas Chromatography/Mass Spectrometry (GC/MS). Both main and supporting parameters were analyzed descriptively.

\section{Addition of oil sludge medium with inoculum}

Medium oil sludge $30 \%$ mixed with sand, soil (2:1). In the present study, $25 \%$ of each VC, SMS, DC and L were added from their total amount $(500 \mathrm{~g})$. The combination applied on each treatments are described in Table 1.

\section{Results and Discussion}

\section{Effect of different types of inoculum on TPH content}

In the present work, TPH content in the medium containing $30 \%$ of oil sludge with the addition of four different types of inoculums were analyzed using Soxhlet during 45 days of experiment. The initial TPH content in $100 \%$ of oil sludge was $29.50 \%$. Significant decrease in TPH content occurred in all types of inoculum (Figure 1). The highest diminution in TPH content was found in SMS inoculum (27.7\%). On the other hand, DC, VC and L inoculum showed lower percentage in TPH reduction, as much as $24.8 \%, 20.9 \%$ and $24.20 \%$, respectively.

Our results indicate that the SMS inoculum gave significant result in reducing TPH content. According to Black and Hannah mycelium

\begin{tabular}{|c|c|c|c|c|c|c|c|}
\hline \multirow{2}{*}{ Treatment } & \multicolumn{7}{|c|}{ Types of inoculum } \\
\cline { 2 - 8 } & $\begin{array}{c}\text { Oil sludge } \\
\text { (\%) }\end{array}$ & Soil (\%) & $\begin{array}{c}\text { Sand } \\
\text { (\%) }\end{array}$ & VC (\%) & $\begin{array}{c}\text { SMS } \\
\text { (\%) }\end{array}$ & DC (\%) & L (\%) \\
\hline P1 & 30 & 30 & 15 & 25 & - & - & - \\
\hline P2 & 30 & 30 & 15 & - & 25 & - & - \\
\hline P3 & 30 & 30 & 15 & - & - & 25 & - \\
\hline P4 & 30 & 30 & 15 & - & - & - & 25 \\
\hline
\end{tabular}

Table 1: Composition of treatment.

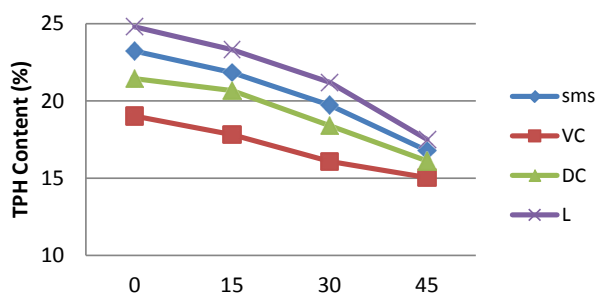

Figure 1: The average of TPH content (\%) on different types of inoculum during 45 days of experiment.

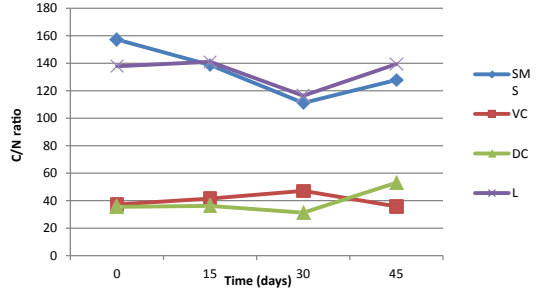

Figure 2: Average of $\mathrm{C} / \mathrm{N}$ ratio in different types of inoculum during 45 days of experiment.

of white oyster mushroom (Pleurotus ostreatus) produces ligninolytic enzymes, including several enzymes that collaborate to decrease lignin. The main enzymes involved in lignilolytic system are lignin peroxidase, laccase, peroxidase and manganese peroxidase. In this case, $P$. ostreatus produce laccase, manganese peroxidase and lignin peroxidase. Furthermore, these ligninolytic enzymes have the ability to break down the complex molecules in crude oil. Therefore, the TPH reduction in SMS inoculum was probably due to the presence of these enzymes. Additionally, difference responses of each inoculum to TPH content during the remediation process could also be due to the variation in nutrient that present in inoculum (Table 1).

According to the criteria from Hardjowigeno [8], Total Nitrogen $(\mathrm{N})$, Phosphorus $(\mathrm{P})$ and Potasium $(\mathrm{K})$ for more than $0.75,0.035$ and 0.006 , respectively, are extremely high. These high nutrient content will affect the microbial degradation of hydrocarbons due to their nutritional needs throughout the remediation.

Nutrition is an essential factor in the synthesis dan growth of cells in enzyme activities, which produced by bacteria in degrading pollutants. Indeed, the $\mathrm{C}, \mathrm{N}$ and $\mathrm{P}$ are the essential nutrition for the microorganisms. For instance, Carbon will be used as the source of energy for supporting their activities. While Nitrogen and Phosphorus are the constituents of significant compounds in cells that determine the growth activity of microorganisms. Additionally, the $\mathrm{N}$ also has a significant role in the preparation of nucleic acids, amino acids and enzymes. On the other hand, the $\mathrm{P}$ element has crucial role in nucleic acid and phospholipid formation. Therefore, these three elements should be presence in appropriate ratio to obtain optimum microbial growth [9].

The microorganisms have the ability to degrade hydrocarbon compounds due to the ezymes that they produce, which enable them to break down the complex organic compounds into simpler compounds. Indeed, enzymes such monoxygenase and dioxygenase are able to open the carbon bonds and produce primary alcohols [10].

\section{Effect of different types of inoculum on $\mathrm{C} / \mathrm{N}$ ratio}

In the present study, the initial $\mathrm{C} / \mathrm{N}$ ratio in oil sludge $100 \%$ was 149.45. Curtailment in $\mathrm{C} / \mathrm{N}$ ratio during 45 days of remediation is presented in Figure 2. The $\mathrm{C} / \mathrm{N}$ ratio decreased in SMS and VC inoculum with $18 \%$ and $4 \%$ of reduction compared to the initial. On the other hand, augmentation in $\mathrm{C} / \mathrm{N}$ ratio occurred in DC and $\mathrm{L}$ inoculum as much as $33 \%$ and $1.14 \%$, respectively. The initial $\mathrm{C} / \mathrm{N}$ ratio reduced in oil sludge medium with $\mathrm{VC}$ inoculum after the treatment. Interestingly, this value increased from 15 to 30 days and then decreased to 35.85 in day 45. In contrast, oil sludge with DC and L inoculum showed fluctuation in $\mathrm{C} / \mathrm{N}$ ratio during the experiment and finally increased at the end of experiment ( $\mathrm{d} 45$ ). Additionally, $\mathrm{C} / \mathrm{N}$ ratio in SMS inoculum initially increased to 157.24 but then slightly decreased on day 15 and became 127.8 at the end of the experiment (Figure 2). 
Citation: Rossiana N, Indrawati I, Mustika Y (2017) Application of Vermicompost, Spent Mushroom Substrate, Domestic Compost and Leachate as Inoculum on Bioremediation of Oil Sludge. J Pet Environ Biotechnol 8: 351. doi: 10.4172/2157-7463.1000351

Page 3 of 5

Our results revealed that $\mathrm{DC}$ had higher $\mathrm{C} / \mathrm{N}$ ratio compared to $\mathrm{VC}$ inoculum (16.24 and 15.76, respectively). However, these $\mathrm{C} / \mathrm{N}$ ratio value in both types of inoculum are still in the allowed level in national standard (SNI 19-7030-2004), which were between 10 and 20. On the other hand, the $\mathrm{C} / \mathrm{N}$ ratio in $\mathrm{L}$ was much lower than that of SNI. In contrast, $\mathrm{C} / \mathrm{N}$ ratio in SMS medium was much higher that the allowed amount in SNI.

\begin{tabular}{|c|c|c|c|}
\hline \multirow{2}{*}{ Types of inoculum } & \multicolumn{3}{|c|}{ Types of nutrient } \\
\cline { 2 - 4 } & Nitrogen (\%) & Phosphorus (\%) & Potassium (\%) \\
\hline SMS & 0.39 & 0.24 & 0.08 \\
\hline VC & 2.26 & 5.03 & 0.95 \\
\hline DC & 2.23 & 5.10 & 0.51 \\
\hline L & 0.32 & 0.10 & 0.87 \\
\hline
\end{tabular}

Table 2: Nutrient content in each types of inoculum.

\begin{tabular}{|c|c|c|c|}
\hline \multirow{2}{*}{ Types of Inoculum } & \multicolumn{3}{|c|}{ Parameters measured } \\
\cline { 2 - 4 } & Total C (\%) & Total Nitrogen (\%) & C/N ratio \\
\hline SMS & 34.43 & 0.39 & 88.28 \\
\hline VC & 2.26 & 2.26 & 15.76 \\
\hline DC & 36.23 & 2.23 & 16.24 \\
\hline L & 1.59 & 0.32 & 4.96 \\
\hline
\end{tabular}

Table 3: Total $\mathrm{C}, \mathrm{N}$ and $\mathrm{C} / \mathrm{N}$ ratio at different types of inoculum.

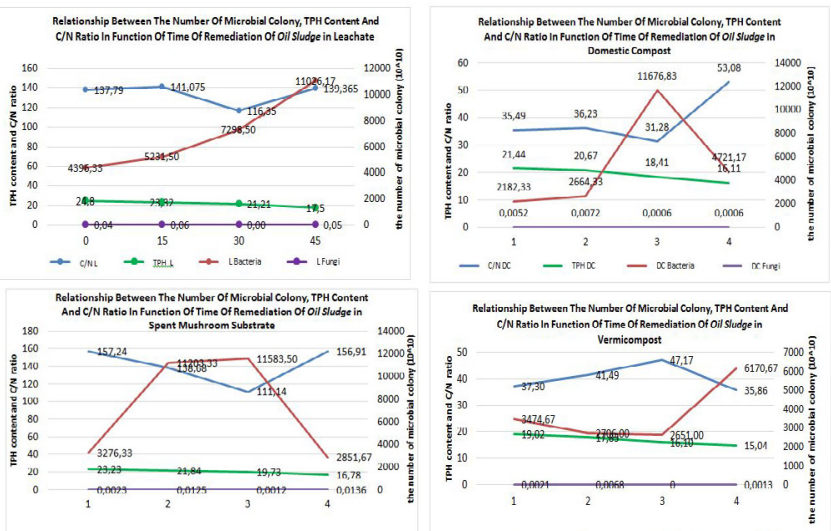

Figure 3: Relationship between TPH content, $\mathrm{C} / \mathrm{N}$ ratio and the number of microbial colony in function of time.
High value in $\mathrm{C} / \mathrm{N}$ ratio in SMS inoculum (88.28) causes higher $\mathrm{C} / \mathrm{N}$ ratio produced during remediation, which is higher than that of VC and DC inoculum. The SMS inoculum contains sawdust, which is a bran as fungal hyphae medium consisting cellulose. According to Ghassani [11], the cell wall of fungi is composed by lignin, which is a carbohydrate-containing polysccharide with a complex wall structure chain and chitin $\left(\mathrm{C}_{8} \mathrm{H}_{13} \mathrm{O}_{5} \mathrm{~N}\right)_{n}$. This may explain the high carbon content and $\mathrm{C} / \mathrm{N}$ ratio oberved in the medium (Tables 2 and 3 ).

In general, decomposition releases carbon dioxide, thus higher microbial activity can accelerate decomposition of organic materials. Therefore, the organic carbon could decrease while the total $\mathrm{N}$ increase, which may reduce the $\mathrm{C} / \mathrm{N}$ ratio. Additionally, the higher total- $\mathrm{N}$ formed could also decrease $\mathrm{C} / \mathrm{N}$ ratio. Indeed, a low $\mathrm{C} / \mathrm{N}$ ratio indicates that mineralization works well [12].

The degraded polyhydrocarbon will produce new compounds either in a polyaromatic form (ring-shaped hydrocarbon) or a polyalkyclic (double hydrocarbon chain), which may increase or decrease the carbon element. In addition, the $\mathrm{N}$ content in oil sludge and all three inoculum cause modification in $\mathrm{N}$ element by the microbes hence changing $\mathrm{C} / \mathrm{N}$ ratio [13].

Correlation between $\mathrm{TPH}, \mathrm{C} / \mathrm{N}$ ratio and the number of microbial colonies in function of remediation time

In this present work, the calculation of the number of microbial colonies (fungi and bacteria) was performed by Total Plate Count (TPC) method. According to Vasudevan and Rajaram [14], the number of microbial population plays crucial role in increasing the rate of hydrocarbon degradation. Indeed, the number of microbial population is positively correlated with the hydrocarbon degradation. In this study, relationship between the number of microbial colony, $\mathrm{TPH}$ content and $\mathrm{C} / \mathrm{N}$ ratio in function of time of remediation of oil sludge $30 \%$ is presented in Figure 3.

In remediation of oil sludge $30 \%$ with different types of inoculum, the role of bacteria appeared to be more dominant than fungi, indicating that indigenous bacteria in each inoculum were more adaptable in the medium (Figure 3). In each inoculum, the fungal colonies grew actively and increased only on day- 0 until day- 15 , and then the growth was very limited (day-30). On day-45, fungal colony re-grew but still lower than in day-30. The fluctuation in the number of microbial colony in the medium of oil sludge $30 \%$ with different types of inoculum indicates that

\begin{tabular}{|c|c|c|c|c|c|c|c|c|c|c|}
\hline \multirow{2}{*}{ No } & \multirow{2}{*}{ PAH Compounds } & \multirow{2}{*}{ C \&H } & \multicolumn{4}{|c|}{ Area/Height $(\mathrm{A} / \mathrm{H}) \mathrm{ke}-0\left(\mathrm{~mm}^{2}\right)$} & \multicolumn{4}{|c|}{ Area/Height $(\mathrm{A} / \mathrm{H}) \mathrm{ke}-45\left(\mathrm{~mm}^{2}\right)$} \\
\hline & & & SMS & VC & DC & $\mathbf{L}$ & SMS & VC & DC & $\mathbf{L}$ \\
\hline 1 & Hexane & $\mathrm{C}_{6} \mathrm{H}_{14}$ & 1.19 & 1.21 & 1.19 & 1.11 & 1.14 & 0.94 & 1.12 & 1.13 \\
\hline 2 & Cyclopentane & $\mathrm{C}_{6} \mathrm{H}_{12}$ & 1 & 0.93 & 1.02 & 0.99 & 0.95 & TD & 0.93 & 0.98 \\
\hline 3 & Tetracosane & $\mathrm{C}_{30} \mathrm{H}_{62}$ & - & 2.26 & 2.23 & - & - & TD & TD & - \\
\hline 4 & Hexadecane & $\mathrm{C}_{20} \mathrm{H}_{42}$ & 2.29 & TD & 2.23 & 2.22 & 2.12 & 2.18 & 2.22 & 2.19 \\
\hline 5 & Hexatriacontane & $\mathrm{C}_{36} \mathrm{H}_{74}$ & 2.03 & 2.38 & 1.79 & 2.07 & 1.94 & 3.8 & 2.09 & 1.88 \\
\hline 6 & Tetrapentacosan & $\mathrm{C}_{54} \mathrm{H}_{110}$ & 2.6 & - & 2.29 & 2.3 & 1.44 & - & 2.14 & 1.72 \\
\hline 7 & Dotriacontane & $\mathrm{C}_{32} \mathrm{H}_{66}$ & 1.87 & - & 1.8 & 3.1 & 1.49 & - & 1.98 & 1.62 \\
\hline 8 & Pentacosane & $\mathrm{C}_{25} \mathrm{H}_{52}$ & TD & - & - & - & 1.69 & - & - & - \\
\hline 9 & Pentadecane & $\mathrm{C}_{19} \mathrm{H}_{40}$ & 1.91 & TD & - & - & TD & 2.18 & - & - \\
\hline 10 & Tricosane & $\mathrm{C}_{23} \mathrm{H}_{48}$ & 2.11 & - & - & 2.4 & TD & - & - & 2.46 \\
\hline 11 & 9-Octadecenoic acid, methyl ester & $\mathrm{C}_{19} \mathrm{H}_{36} \mathrm{O}_{2}$ & - & - & - & 1.92 & - & - & - & TD \\
\hline 12 & Hexacosane & $\mathrm{C}_{26} \mathrm{H}_{54}$ & - & - & - & 1.8 & - & - & - & TD \\
\hline 13 & Di-9Octadecenoyl)-Glycerol & $\mathrm{C}_{39} \mathrm{H}_{72} \mathrm{O}_{5}$ & - & 1.13 & - & - & - & 2.41 & - & \\
\hline 14 & n-Eicosanol & $\mathrm{C}_{20} \mathrm{H}_{42}$ & - & 3.58 & - & - & - & 2.31 & - & \\
\hline 15 & Heptadecane & $\mathrm{C}_{21} \mathrm{H}_{44}$ & - & TD & - & - & - & 1.91 & - & \\
\hline
\end{tabular}

Table 4: The identified polycyclic aromatic hydrocarbon (PAH) compounds in the medium. 
Citation: Rossiana N, Indrawati I, Mustika Y (2017) Application of Vermicompost, Spent Mushroom Substrate, Domestic Compost and Leachate as Inoculum on Bioremediation of Oil Sludge. J Pet Environ Biotechnol 8: 351. doi: 10.4172/2157-7463.1000351

\begin{tabular}{|c|c|c|c|c|c|c|c|c|c|c|}
\hline \multirow{3}{*}{ Inoculum } & \multicolumn{10}{|c|}{ Heavy metals } \\
\hline & \multicolumn{2}{|c|}{$\mathrm{Pb}$ (ppm) } & \multicolumn{2}{|c|}{$\mathrm{Ni}(\mathrm{ppm})$} & \multicolumn{2}{|c|}{ Cd (ppm) } & \multicolumn{2}{|c|}{$\operatorname{Cr}(p p m)$} & \multicolumn{2}{|c|}{$\mathrm{Hg}$ (ppm) } \\
\hline & $\mathrm{H}-\mathrm{O}$ & H-45 & $\mathrm{H}-\mathrm{O}$ & H-45 & $\mathrm{H}-\mathrm{O}$ & H-45 & $\mathrm{H}-\mathrm{O}$ & H-45 & $\mathrm{H}-\mathrm{O}$ & $\mathrm{H}-45$ \\
\hline Vermi & 24 & 26 & $<5$ & $<5$ & $<0.02$ & $<0.02$ & 13 & 15 & 92 & 180 \\
\hline $\begin{array}{l}\text { Spent Mushroom } \\
\text { substrate }\end{array}$ & 26 & 75 & $<5$ & $<5$ & $<0.02$ & $<0.02$ & 18 & 15 & 136 & 132 \\
\hline Domestic compost & 22 & 24 & $<5$ & $<5$ & $<0.02$ & $<0.02$ & 11 & 18 & 146 & 141 \\
\hline Leachate & 34 & 38 & $<5$ & $<5$ & $<0.02$ & $<0.02$ & 17 & 16 & 170 & 180 \\
\hline
\end{tabular}

Table 5: The average of heavy metals content at different types of inoculum.

the indigenous microbes in each inoculum were able to adapt and use the hydrocarbon as the source of energy. These microorganims also utilize the nutrients present in each inoculum for their survival (Table 4).

Fungi are the main component in biodegradation of hydrocarbon. Furthermore, biodegradation product by the fungal organism will be utilized by the bacteria thus facilitating the competition of growth between the fungi and bacteria in the medium. Indeed, the high population of bacteria suppresses the growth of fungi that may decrease the fungal population [13].

The TPH content decreased during the remediation. This reduction may lead to the formation of new toxic compounds such as polyaromatic hydrocarbon (PAH) thus lowering the number of microbial colony and provokes the augmentation in $\mathrm{C} / \mathrm{N}$ ratio. According to Rossiana [13], the degraded polyhydrocarbon could produce new compounds in both polyaromatic form and polyalisyclic that probably may increase or decrease the carbon content.

\section{Effect of different types of inoculum on polycyclic aromatic hydrocarbon}

The PAH contet was analyzed at the beginning (day 0$)$ and the end of remediation experiment (day 45). In this study, a total of 15 hydrocarbon compounds were detected in all four types of inoculum that consist of; Hexane, Cyclopentane, Hexadecane, Hexatriacontane, Dotriacontane, Tetrapentacosan and Dotriacontane. These compounds have a range of carbon chains from $\mathrm{C}_{6}-\mathrm{C}_{54}$. Indeed, change in proportion of each of these compounds during remediation was occurred (Table 5).

Degradation of Pentadecane and Tricosane compounds was detected in SMS medium (Table 5), until both of them were undetected at day 45 and replaced by new compound (Pentacosane). On the other hand, the Cyclopentane and Tetracosane compounds were undetected in VC inoculum, but three other new compounds (Hexadecane, Pentadecane and Heptadecane) appeared at day 45. In DC inoculum, only one compound (Tetracosane) that was undetected at day 45 , while in L inoculum the 9-Octadecenoic acid, methyl ester and Hexacosane remain undetected. Furthermore, other compounds found in oil sludge medium decreased qualitatively based on the observation of their surface area from the beginning until the end of observation.

In this study, the change in the range of carbon chains and the amount of detected compounds during remediation indicate degradation of complex carbon chains into the non-complex carbon chains as consequence of microbial activity. This result confirms the previous study by Nugroho [10] that the presence of microbial activity could degrade oil sludge by fragmenting the long-chain aliphatic hydrocarbon component and transforming the aromatic hydrocarbon compound. Therefore, change in composition of the constituent hydrocarbon fraction can be revealed in oil sludge. Indeed, fragmentation in the heavy fraction of hydrocarbon bonds may affect a rapid multiplication in lighter fraction of hydrocarbon.
Degradation of PAH is closely related to the mechanism of action of dioxygenase and dehydrogenase enzymes. The first step in PAH degradation involves oxygen atoms on 2 carbon in the structure of benzene by dioxygenase enzyme. This interaction produces the structure of cis-dihydriol. Afterwards, dehydrogenase enzyme can trigger re-aromatization on the structure, thus the dihydroxylated intermediet is formed. This structure then undergo the cleavage of aromatic ring to form the tricarboxylic acid cycle (TCA) intermediet, which subsequently become non-complex structure thus it can be processed into the source of energy [15].

\section{Effect of different types of inoculum on heavy metals}

In this study, heavy metals were analyzed at the beginning (day 0 ) and end of the remediation experiment (day 45). According to the Government Regulation of Indonesian Republic No. 85/1999 on the management of hazardous and toxic wastes, the maximum allowed limit of $\mathrm{Pb}, \mathrm{Ni}, \mathrm{Cd}, \mathrm{Cr}$ and $\mathrm{Hg}$ were $5.0 \mathrm{ppm}, 0.4 \mathrm{ppm}, 1.0 \mathrm{ppm}, 5.0$ $\mathrm{ppm}$ and $0.2 \mathrm{ppm}$, respectively. However, our study revealed that most of these heavy metals (except $\mathrm{Cd}$ ) exceeded the allowed limit.

In general, $\mathrm{Pb}$ content in all types of inoculum in oil sludge medium increased. Indeed, the highest augmentation in $\mathrm{Pb}$ content was found on SMS inoculum (188\%) as compared to other types of inoculum. The increased in $\mathrm{Pb}$ content for VC, DC and L were as much as $8.33 \%$, $9.09 \%$ and $11.7 \%$, respectively. In contrast, there was no change in both $\mathrm{Ni}$ and $\mathrm{Cd}$ content from the beginning (day 0 ) to the end of experiment (day 45). The content of $\mathrm{Cr}$ decreased in both oil sludge medium with SMS and L inoculum as much as $16 \%$ and $5.88 \%$, respectively whereas the increase of $\mathrm{Cr}$ was observed in both VC (15\%) and DC (63.6\%) inoculum. Interestingly, the $\mathrm{Hg}$ content increased only in SMS inoculum (29\%), but not on DC, L and VC inoculum.

Reduction in heavy metals content occurs naturally due to the presence of microorganisms that are able to grow, adapt and reproduce in their environment. Indeed, the dominant microorganisms that developed during remediation are the microbes. According to Vijayaraghavan and Sang Yun, bacteria are considered as heavy metals biosorbent agent. Indeed, the mechanism of heavy metal biosorption by microorganisms is a complex process that consists of transportation of heavy metals through cell membranes, ino exchange and production of organic acids by the bacteria. Additionally, Sayer and Gadd observe that one of chelator produced by fungi is oxalic acid. This type of acid is produced by microbes and can increase microbial resistance to metals via the formation of insoluble metal-oxalic complexes.

Evelyn [16] observed that the enlargement of heavy metals content in the medium is perhaps due to the accumulation of dead metals by the bacteria then these metals were released back to bind with the soil colloids thus increasing the metal content in the soil.

\section{Effect of acidity $(\mathrm{pH})$, temperature and humidity of medium in each inoculum}

The main component in bioremediation is the bacteria as biodegradation agent and the product produced such as converting or mineralizing the contaminants thereby reducing their mass and toxicity that are different from most other components on their environment. The success of bioremediation is influenced by three crucial factors: the microbial availability, contaminants accessibility and favorable environment. Indeed, the efficiency of bioremediation depends on the ability of microbes to degrade complex compounds to non-complex compounds [17]. 
Citation: Rossiana N, Indrawati I, Mustika Y (2017) Application of Vermicompost, Spent Mushroom Substrate, Domestic Compost and Leachate as Inoculum on Bioremediation of Oil Sludge. J Pet Environ Biotechnol 8: 351. doi: 10.4172/2157-7463.1000351

The supporting parameters measured in this study are temperature, acidity and humidity. The temperature in all treatments during remediation ranged from $25^{\circ} \mathrm{C}$ to $28^{\circ} \mathrm{C}$. Udiharto reported that the optimum temperature for bioremediation of oil sludge range from $25^{\circ} \mathrm{C}$ to $40^{\circ} \mathrm{C}$, due to the requirement of mesophilic bacteria that live in that range of temperature in order to enhace bioremediation. Thus, the temperature obtained in this study are still in optimum range. On the other hand, our results revealed that the $\mathrm{pH}$ in the medium decreased after 6 weeks of remediation. This diminution is probably due to the bacterial metabolism activity in oil degradation that produce fatty acids as final products [18].

In the present work, the average of humidity ranged from $47 \%$ to 54\%. According to Cookson [19], the optimum humidity for bioremediation of oil sludge and its derivatives is approximately $50 \%$ to $60 \%$. Moreover, inadequate humidity (i.e., less than $40 \%$ ) could limit the rate of bioremediation, while the soil humidity above $70 \%$ could disrupt oxygen transfer thus reducing aerobic activity.

\section{Conclusion}

Our results revealed that the four types of inoculum: SMS, VC, DC and L, affect the decrease of TPH content as much as $27.7 \%, 20.9 \%$, $24.8 \%$ and $24.20 \%$, respectively. The SMS and VC are able to reduce $\mathrm{C} / \mathrm{N}$ ratio as much as 18 and $4 \%$, respectively. While the DC and L inoculum increased $\mathrm{C} / \mathrm{N}$ ratio as much as $33 \%$ and $1.14 \%$, respectively. The SMS and L inoculum decrease the $\mathrm{Cr}$ content as much as $16 \%$ and $5.88 \%$, respectively whereas $\mathrm{Hg}$ content reduced to $29 \%$ in oil sludge with SMS inoculum. Furthermore, $\mathrm{PAH}$ could be degraded by all types of inoculum, from the complex carbon chain $\left(\mathrm{C}_{6}-\mathrm{C}_{54}\right)$ into the noncomplex carbon chain $\left(\mathrm{C}_{6}-\mathrm{C}_{30}\right)$ Our results suggest that longer period of time required degrading oil sludge $30 \%$ to significantly reduce $\mathrm{TPH}$, $\mathrm{C} / \mathrm{N}$ ratio, $\mathrm{PAH}$ and heavy metals content as regulated in the national standard. In addition, further studies are required to identify the microbes in each inoculum that affect biodegradation of oil sludge.

\section{Acknowledgements}

The authors wish to thank to the Universitas Padjadjaran for their financial support through ALG Prof Poniah Andayaningsih project from Universitas Padjadjaran. We would like also to express our gratitude to the technicians involved in ALG project in the Department of Biology, Universitas Padjadjaran, for their technical assistance during the experiment.

\section{References}

1. Basumatary B, Saikia R, Bordoloi S (2012) Phytoremediation of crude oil contaminated soil using nut grass, Cyperus rotundus. J Environ Biol 33: 891-896.

2. Peraturan Pemerintah Republik Indonesia Nomor 101 Tahun (2014) Tentang Pengelolaan Limbah Bahan Berbahaya dan Beracun. Jakarta.
3. Keputusan Menteri Negara Lingkungan Hidup Nomor 128 (2003) Tentang Tata Cara dan Persyaratan Teknis Pengolahan Limbah Minyak Bumi dan Tanah Terkontaminasi Oleh Minyak Bumi Secara Biologis. Jakarta.

4. Chevron P (2012) Bioremediasi dalam Penambangan Minyak Mentah. Lembar Fakta Bioremediasi.

5. Surtikanti HK (2011) Toksikologi Lingkungan dan Metode Uji Hayati. Rizq Press. Bandung.

6. Darmawan P, Hatiningrum WR, Raharjo MS (2015) Bioremediasi Pada Tanah Terkontaminasi Minyak Bumi. Jurnal ESDM 7: 61-70.

7. Rahman JAF (2011) Bioremediasi Lumpur Minyak (Oil Sludge) dengan Penambahan Kompos sebagai Bulking Agent dan Sumber Nutrien Tambahan. Jurnal Sains dan Teknologi Lingkungan.

8. Hardjowigeno S (2003) IImu Tanah. Akademika Pressindo. Jakarta.

9. Wulan PDK, Gozan M, Arby B, Achmad B (2015) Penentuan Rasio Optimum C:N:P Sebagai Nutrisi Pada Proses Biodegradasi Benzena-Toluena Dan Scale Up Kolom Bioregenerator. Departemen Teknik Kimia, Fakultas Teknik, Universitas Indonesia. Depok.

10. Nugroho A (2006) Bioremediasi Hidrokarbon Minyak Bumi. Penerbit Graha IImu. Yogyakarta.

11. Ghassani M, Ghassani ZG (2014) Pengaruh talaromyces sp., Cladosporium sp. Dan Sengon (Paraserianthes falcataria L. Nielsen) Bermikoriza Terhadap Kada Total Petroleum Hydrcarbon (Tph) Dan C/N Rasio Dalam Fitoremediasi Oil Sludge. Skripsi. Sumedang: Biologi Universitas Padjadjaran Universitas Padjajaran.

12. Pujiono PW, Widyorini N, Ain C (2016) Analisis C/N rasio dan Total Bakteri pada Sedimen Kawasan Konservasi Mangrove Sempadan Sungai Betahwalang dan Sungai jajar Demak. UNDIP. Semarang. Prosiding Seminar Nasional Tahunan $\mathrm{Ke}-\mathrm{V}$ Hasil-Hasil Penelitian Perikanan dan Kelautan.

13. Rossiana N, Wulandari AP, Rescho FAS, Ghassani FZ (2015) Biosurfactants activity from exogenous fungi to decreasing total petroleum hydrocarbon (tph) of balongan oil sludge. Asian Jr. of Microbiol Biotech Env Sci 17: 781-784.

14. Rajaram VD, Vasudevan N, Rajaram P (2001) Bioremediation of oil sludge contaminated soil. Environ Int. 26: 409-411.

15. Hawumba JF, Sseruwagi P, Hung YT, Wang LK (2010) Bioremediation in Wang LK (ed) Handbook of Environmental Engineering 11: 277-316.

16. Caesarina EH (2015) Fitoremediasi oil sludge dengan menggunakan konsorsium bakteri (Bacillus sphaericus dan Pseudomonas aeruginosa) dan Sengon (Paraserianthes falcataria (L.) Nielsen) bermikoriza terhadap kadar $\mathrm{Pb}$ dan Ni. Skripsi. Sumedang: Biologi Universitas Padjadjaran Universitas Padjajaran.

17. Qomarudin H, Laksmono R, Kardena E (2015) Bioremediation of aged petroleum oil contaminated soil: From laboratory scale to full scale application. Procedia Chemistry, Elsevier, The Netherlands. 14: 326-333.

18. Nugroho A (2009) Produksi gas hasil biodegradasi minyak bumi: Kajian Awa Aplikasinya dalam Microbial Enhanced Oil Recovery (MEOR). Makara, Sains 13: $111-116$

19. Cookson JT (1995) Bioremidition engineering: Design and application McGraw-Hill, New York, USA 